\title{
Effect of Procurement Policy on aid Inflows in the Pacific: Accounting for Economic Growth and Financial Development in Fiji
}

\author{
Ronald Ravinesh Kumar, Arvind Patel, Madhukar Singh \\ University of the South Pacific \\ Laucala Campus, Suva, Fiji Islands \\ E-mail.kumar_rn@usp.ac.fj; arvind.patel@usp.ac.fj; madhukar.singh@usp.ac.fj \\ cross $^{\text {ref }}$ http://dx.doi.org/10.5755/j01.ee.28.5.17292
}

\begin{abstract}
A detailed public procurement policy in Fiji was just introduced in 2010. However, no study has been done to examine the impact of the policy on the aid inflows. In this study, we examine the short-run and long-run impact of adopting the (new) public procurement policy on the aid inflows from the bilateral donors: Australia, the United Nations (UN), the European Union (EU), Japan, the Republic of Korea, France, and Germany. The autoregressive distributed lag (ARDL) procedure is used to examine co-integration and the subsequent short-run and long-run effects. Additionally, the model incorporates per capita income, financial development, and crisis as a structural dummy; and the presence of threshold effect on aid inflows is examined. The results show that procurement legislation, financial development, per capita income and crisis have a long-run association with aid inflows. The new public procurement legislation has a positive effect on aid inflows from Australia, the EU, Germany, and the total aid. In the short-run, procurement legislation has a positive effect on aid inflows from the Republic of Korea only; and the procurement policy and financial development have a long-run positive effect on aid inflows to Fiji. Overall, improved procurement policies, a well-developed financial sector and a reasonable level of growth is necessary to bolster aid inflows, whereas political uncertainty and global financial crisis has a retarding effect on aid inflows.
\end{abstract}

Keywords: Aid Inflows, Procurement Policy, Financial Development, Economic Growth, Pacific, Fiji.

\section{Introduction}

The study examines whether public procurement policies, financial development and economic growth are associated with the flow of aid or the Official Development Assistance (ODA) to Fiji, a small and developing island nation in the South-West Pacific. Similar to other small Pacific island countries (PICs), Fiji receives substantial amount of aid. Like all forms of aid, the main goal is to alleviate poverty and support economic growth of the developing states. This view has also been reinforced by prior research (Arrowsmith, 1995; Knight et al., 2003; Bolton, 2006; Knight et al., 2012). Donor agencies are normally willing to grant aid to PICs that have very efficient and effective procurement policies and procedures.

An efficient procurement policy is essential for national development (c.f. Ahmadu (2005) and the references therein). For efficient channeling of aid, a clear and effective procurement policy is necessary. The effective execution of the policy for aid deployment is a signal to the donors that aid resources are efficiently mobilized in the recipient country and the primary objectives of pro-growth development are targeted. Moreover, the effectiveness of the procurement policy becomes a useful device for donors to assess the recipient's competency in using the aid resources and can influence the amount of future aid flows. A strong and detailed procurement policy and legislation in Fiji was introduced just in 2010. In this study, we contribute to the literature by examining the impact of the procurement policy on the aid inflows in Fiji. We analyze the short-run and long-run impact of adopting the (new) public procurement policy on aid inflows from the bilateral donors:
Australia, the United Nations (UN), the European Union (EU), Japan, the Republic of Korea, France, and Germany. The autoregressive distributed lag (ARDL) procedure is used to examine co-integration and the subsequent short-run and long-run effects. Additionally, the model incorporates per capita income, financial development, and crisis as a structural dummy; and the presence of threshold effect on aid inflows is examined.

The PICs consist of more than 23 countries spread over 20 million square miles of the Pacific Ocean with population ranging from 1000 to 3.5 million people. Several PIC economies are mostly dependent on services sector (such as tourism) because the manufacturing sector remains underdeveloped, and the primary sector such as agriculture is experiencing severe decline. A major reason for the decline in primary and underdevelopment of the secondary sector is the isolation of PICs from the main trading routes by air or sea. The migration of young and educated people to developed countries has also stunted the growth of key sectors in PIC economies. However, recent developments in information and communication technologies (ICTs) and tourism are some solutions to the problems related to remoteness, low productivity and poor health services (Jayaraman, Chen \& Bhatt, 2014; Kumar \& Kumar, 2012; Kumar \& Singh 2014; Kumar, Kumar \& Patel, 2015).

The role of financial development in Fiji has not been very supportive of economic growth. Gounder (2012) examines the association between financial development and economic growth in Fiji, from 1970 to 2005. The results show that financial development has a positive association with economic growth only in the short-run and a marginal negative association in the long-run. In another study, 
Makun (2016) explores the determinants of foreign direct investment in Fiji over the periods 1980-2015 and notes, inter alia, that although financial development has a positive influence, it is not statistically significant. According to Gounder (2012), reasons for weak contribution of financial development is due to the thin financial market, financial sector mainly serving the urban population and excluding rural entrepreneurs, the less important role of banks with regards to savings and loans compared to the Fiji National Provident Fund as a major investor, the interest rate control of pre-1987 periods, and the combined effects of financial liberalization of the late 1980s and the collapse of the National Bank of Fiji in the mid-1990s.

Nevertheless, all these challenges restrict PIC governments from heavily relying on the private sectors to drive major economic activities, and government intervention becomes a requirement for growth. However, given the low levels of economic activities in PICs, even the governments are unable to generate sufficient revenue to provide the fiscal stimulus and hence have to rely on donor funding for important capital projects such as roads, health services, ICT and education.

The huge reliance on donor funding to support its economic development and propel growth requires serious efforts to minimize wastage of aid resources largely resulting from fraudulent procurement practices and/or weak procurement policies (Jones, 2013). In some instances, if it is suspected that PIC's procurement policies and regulations are weak, the aid agencies circumvent the problems by conditioning their own procurement policies and providing staff to implement their projects. Another challenge is that PICs do not have well developed and competitive markets to ensure efficient public sector procurement, which is compounded by the lack of skilled personnel and experts in the public sector procurement process. Additionally, the interplay of specific cultural and customary practices with specific procurement policies and regulation affects the effective deployment of aid through the public sector procurement process. Therefore, the flow and effectiveness of aid to the recipient countries are incumbent on the sound procurement policy or legislation.

In any case, the motivations for aid from bilateral and multilateral donors vary. Some donors provide aid to countries, which are developing and experiencing low economic growth, with clear path to progress while others consider a relatively fast growing, albeit a developing country, as effective users of aid resources. Another important dimension that donors consider for successful aid deployment is the recipient countries' procurement policies, by and large, driven by the public sector.

In recent years, aid agencies have emphasized the need for effective and efficient procurement policies, and have directly linked the amount of aid to the effectiveness of the public sector procurement policies. In the case of Fiji, although the Financial Management Act of 2004 provided a very basic framework, there were no detailed guidelines for the public sector procurement processes. In 2006, following the political instability, one of the government's reform initiatives was the introduction of the new Procurement Regulations 2010 legislation (the new procurement policy) which was solely designed to guide the public procurement of goods and services and attract important bilateral aid from donor countries. While the new policy is a welcome news for donors and politicians, to what extent has the policy influenced the flow of aid has not been explored. Hence, this study examines the nexus between public sector procurement policy and procedures and the inflow of aid. Thus, we examine the impact of the procurement policy, financial development and economic growth on the flow of aid from the bilateral donor countries - Australia, the European Union (EU), France, Germany, Japan, the Republic of Korea, and the United Nations (UN).

In general, the results suggest that procurement legislation, financial development, per capita income and crisis have a long-run association with the aid inflows from donor agencies; and that procurement legislation and financial development has a clear positive association with aid inflows to Fiji, whereas crises of internal nature such as political uncertainty and external nature such as the global financial crisis hampers the overall flow of aid to Fiji.

The rest of the paper is outlined as follows. In Section 2, a literature review is provided followed by three propositions which will be examined. Section 3 is on data and methods. Section 4 discusses the results and the final section presents the conclusion of the study.

\section{Literature Review}

Governments play a crucial role in all economies through its policy making abilities. Their redistributive role is designed to rearrange wealth and income among all groups in the society. The distributive role ensures benefits (such as subsidies) are received by groups or industries which are fragile. The third is a regulatory role, where governments can exercise, manage, promote and limit certain activities of citizens and businesses.

An efficient public procurement is an important vehicle for economic growth and development (Arrowsmith 1995, Knight et al., 2003, Bolton, 2006; Knight et al., 2012). An efficient procurement is one which minimizes costs and other negative spillovers associated with government procurement and an effective procurement is one which achieves the desired outcomes. Knight et al. (2003 \& 2012) recommend that stakeholders of the public sector should pay particular attention to achieving the desired outcomes. Schooner and Whiteman (2000) mention that transparency, probity, competition and value for money are also important considerations in a public procurement process.

Since the 1960s, much has been written on the impact of foreign aid on macroeconomic performance and growth, and not all of the studies favour aid as a positive driver of growth (Bornschier et al., 1978; Levy, 1988; McKinnon, 1964; Patrick, 1966). The role of ODA in expediting economic growth is a controversial topic given that there is no unanimity on the impact of aid and the flow and effect are at times, influenced by many of structural factors and politics. However, the motivations of foreign aid are generally modelled in terms of donor interests and the recipient country needs, and improving the growth and international income distribution (Llavador \& Roemer, 2001; Trumbull \& Wall, 1994). A number of studies have shown that development assistance has a positive influence on growth. However, the magnitude of the effect is mainly dependent on the recipient countries policy, aid management strategies, and geopolitical 
factors (Burnside \& Dollar, 2000). On the other hand, there are some studies, which show development assistance can be counterproductive and hence harmful or ineffective, especially when donors direct the use of aid to implement their own projects (Banerjee \& Rondinelli, 2003; Dalgaard, 2008; Dalgaard et al., 2004; Dalgaard \& Hansen, 2001; Hansen \& Tarp, 2001).

Some studies highlight that the positive effect of development assistance is notable for many developing countries in the presence of a stable inflow of aid (Chauvet \& Guillaumont, 2009). However, aid can be harmful for recipient countries when the flows are volatile (Neanidis \& Varvarigos, 2009). Other scholars (Rao, 2010; Shleifer, 2009) contend that aid does not have any significant effect on growth for recipient countries which are small in terms of population size and have weak economic institutions.

Other factors can interplay to determine the impact of aid on growth and development. Some studies point out that the impact of aid inflows are affected by the recipient countries' government performance, income level and the donors own interest (Chong \& Gradstein, 2008; Harrigan \& Wang, 2010). Thus, it is argued that in order for aid allocation and distribution to have an impact on growth, the recipient country governments should incorporate grants in their budgetary decision-making, review the aid apparatus carefully, have an effective governance system and sound procurement related policy (Sobhee \& Nath, 2010; Heckelman \& Knack, 2009; Rajan \& Subramanian, 2007; Burnside \& Dollar, 2000).

Given the country background and the literature, in this paper, three propositions are examined both in the short-run and the long-run: (i) the donors are heterogeneous in terms of the level of economic growth and aid flows; (ii) the financial sector development has a positive influence on the flow of aid from the donors; and (iii) the adaption of an efficient and effective public procurement policy will have a positive effect on the aid from the donors.

\section{Data and Method}

\section{Data}

We extract data on aid (ODA), economic growth measured by gross domestic product (GDP) per capita at 2010 constant US dollars, and financial development measured by domestic credit (\% GDP) from the World Development Indicators and Global Development Finance (World Bank, 2016). The period denoting the adoption of the public procurement aid policy are from 2010 onwards and is denoted by a dummy variable equal to one. Moreover, we create a structural dummy which denotes the three major political crisis in Fiji, in 1987, 2000 and 2006, respectively, and the global financial crisis of 2008. The periods 2007 onwards therefore characterizes the flow on effect of the global financial crisis and the pre-election periods in Fiji following the 2006 political crisis.

\section{Method}

A basic Cobb-Douglas setup is used to formulate a reduced form model as follows:

$$
O D A_{t}=G D P_{t}^{\alpha} F I N_{t}^{\beta}
$$

where aid inflows is the net ODA (official development assistance) from the donors (as a percent of GDP), GDP refers to the real gross domestic product per capita as a measure of economic growth, FIN refers to financial development measured by the domestic credit to private sectors (as a percent of GDP); and $\alpha$ and $\beta$ are the elasticity of ODA with respect the economic growth and financial development.

Taking a log transformation of (1) yields the basic linear in variables model denoting the long-run relationship:

$\ln O D A_{t}=\pi+\delta$ Trend $+\alpha \ln G D P_{t}+\beta \ln F I N_{t}+$ $\vartheta P R O C_{-} L E G_{t}+\theta$ Crisis $_{t}+\varepsilon_{t}$

where $\pi$ is a constant, $\delta$ is the coefficient of time trend (Trend), $\alpha$ and $\beta$ are the elasticity of ODA with respect to economic growth and financial development, respectively; $\vartheta$ refers to the coefficient of public procurement legislation with respect to aid; $\theta$ is the coefficient of crisis which includes political and the global financial crisis of 2007; and $\varepsilon_{t}$ is the error term.

The autoregressive distributed lag (ARDL) equation is expressed as follows:

$\ln O D A_{t}=\phi_{1}+\phi_{2}$ Trend $+\phi_{3} P R O C_{-} L E G_{t}+$ $\phi_{4}$ Crisis $_{t}+\sum_{i=1}^{p_{1}} \gamma_{2 i} \ln O D A_{t-i}+\sum_{i=0}^{p_{2}} \zeta_{2 i} \ln G D P_{t-i}+$ $\sum_{i=0}^{p_{3}} \omega_{2 i} \ln$ FIN $_{t-i}+u_{t}$

where $\phi_{1}, \phi_{2}, \phi_{3}$ and $\phi_{4}$ are coefficients of constant, trend, procurement legislation, and the structural break dummy denoting the crisis period; $\gamma_{2 i}, \zeta_{2 i}$, and $\omega_{2 i}$ are the coefficients of the parsimonious lagged estimates of $\ln O D A_{t-i}\left(i=1, \ldots, p_{1}\right), \quad \ln G D P_{t-i}\left(i=0, \ldots, p_{2}\right) \quad$ and $\ln$ FIN $_{t-i}\left(i=0, \ldots, p_{3}\right)$, respectively.

For the non-linear in variables model estimation, using equation (2) and insights from Tamazian and Rao (2010), Kumar and Stauvermann (2016), and Shahzad et al. (2017), we specify the following:

$\ln O D A_{t}=\pi+\delta$ Trend $+\alpha^{\prime} \ln G D P_{t}+\alpha^{\prime \prime}\left(\ln G D P_{t}\right)^{2}+$ $\beta \ln$ FIN $_{t}+\vartheta P R O C_{-} L E G_{t}+\theta$ Crisis $_{t}+\varepsilon_{t}$

where $\alpha^{\prime}$ and $\alpha^{\prime \prime}$ is the coefficient of $\ln G D P_{t}$ and $\left(\ln G D P_{t}\right)^{2}$, respectively. Since $\alpha^{\prime} \neq \alpha^{\prime \prime}$, the $\alpha^{\prime}$ should not be interpreted directly as the respective share of GDP (see Kumar \& Stauvermann, 2016).

\section{Estimation Technique}

\section{ARDL Bounds Procedure}

The ARDL method (Pesaran, et al., 2001) is preferred because unlike other co-integration tests (Engle \& Granger 1987; Johansen \& Juselius 1990), the procedure does not require the test of unit root properties as long as stationarity is confirmed in the first difference form of the variables. Furthermore, the ARDL procedure is simple and provides robust results in the presence of small sample size (Odhiambo, 2009; Kumar \& Stauvermann, 2014). For the purpose of bound testing approach to co-integration, we capture the relationship of equation (2) and (4) by specifying the following ARDL equations, respectively:

$$
\begin{aligned}
& \Delta \ln O D A_{t}=\pi_{10}+\pi_{11} \ln O D A_{t-1}+\alpha_{12} \ln G D P_{t-1} \\
& +\beta_{13} \ln \text { FIN }_{t-1}+\phi_{10} \text { PROC }_{-} L E G+ \\
& \lambda_{10} \text { Crisis }+\varphi_{10} \text { Trend }+\sum_{i=1}^{p} \alpha_{11 i} \Delta \ln G D P_{t-i} \\
& +\sum_{i=0}^{p} \alpha_{12 i} \Delta \ln \text { FIN }_{t-i}+\varepsilon_{1 t}
\end{aligned}
$$




$$
\begin{aligned}
& \Delta \ln O D A_{t}=\pi_{10}+\pi_{11} \ln O D A_{t-1}+\alpha_{12} \ln G D P_{t-1} \\
& +\beta_{13}^{\prime}\left(\ln G D P_{t-1}\right)^{2}+\beta_{13} \ln F I N_{t-1}+\phi_{10} P^{\prime} O C_{-} L E G \\
& +\lambda_{10} \text { Crisis }+\varphi_{10} \text { Trend }+\sum_{i=1}^{p} \alpha_{11 i} \Delta \ln G D P_{t-i} \\
& +\sum_{i=0}^{p} \alpha_{12 i}^{\prime}\left(\Delta \ln G D P_{t-i}\right)^{2}+\sum_{i=0}^{p} \alpha_{13 i} \Delta \ln F_{I N} N_{t-i} \\
& +\phi_{10} \Delta \text { PROC_LEG } \\
& +\lambda_{10} \Delta \text { Crisis }+\varphi_{10} \Delta \text { Trend }+\varepsilon_{2 t}
\end{aligned}
$$

Note the ARDL equations (5.1) and (5.2) contain two dummies representing the procurement legislation and crisis periods, respectively. Next, co-integration is identified in two steps. First, equations (5.1) and (5.2) are estimated separately, using the ordinary least squares technique. The second step requires testing the null hypothesis of no cointegration $H_{N U L L}: \pi_{11}=\alpha_{12}=\beta_{13}=0 \quad\left(H_{N U L L}: \pi_{11}=\right.$ $\alpha_{12}=\beta_{13}^{\prime}=\beta_{13}=0$ ) against the alternative hypothesis of the existence of a long run relationship $H_{A L T}: \pi_{11} \neq$ $0 ; \alpha_{12} \neq 0 ; \beta_{13} \neq 0 \quad\left(H_{A L T}: \pi_{11} \neq 0 ; \alpha_{12} \neq 0 ; \beta_{13}^{\prime} \neq\right.$ $0 ; \beta_{13} \neq 0$ ) to examine co-integration using a linear (nonlinear) equation. The existence of a long run co-integration relationship is examined by reviewing the corresponding upper and lower bounds of $\mathrm{F}$ statistics. Three possibilities are examined: accept co-integration when F-statistics is greater than the respective upper bound $\left\{F>I(1)_{\text {critical }}\right\}$; reject co-integration when F-statistics is below the respective lower bound $\left\{F<I(0)_{\text {critical }}\right\}$; and inconclusive when the F-statistic is within the respective upper and lower bounds, $\left\{I(0)_{\text {critical }}<F<I(1)_{\text {critical }}\right\}$. The F- statistics and the respective upper and lower bounds at $5 \%$ and $10 \%$ levels of statistical significance are derived from (Pesaran $e t$ al., 2001). Eviews 9.0 is used to carry out the estimations. We estimate the equations and examine the coefficients $\alpha^{\prime}$ of $\ln G D P_{t}$ and $\alpha^{\prime \prime}$ of $\left(\ln G D P_{t}\right)^{2}$. Where both $\alpha^{\prime}$ and $\alpha^{\prime \prime}$ are statistically significant within 1-10 percent level of statistical significance, we report the results based on equation 4 (non-linear in variables model), and where $\alpha^{\prime \prime}$ is not statistically significant, we report the results based on equation 2 (linear in variables model).

\section{Results}

\section{Descriptive Statistics}

Table 1 presents the descriptive statistics and the correlation matrix. In terms of correlation, ODA is positively correlated and statistically significant for the following aid agencies pairs: France and Australia $(\rho=0.5097)$, Germany and Australia $(\rho=0.7875)$, and Germany and France $(\rho=$ 0.7369). However, we note that ODA has a negative and significant correlation between the following pairs: Japan and the EU ( $\rho=-0.3578)$, the Republic of Korea and France $(\rho=$ -0.4629), the Republic of Korea and Germany $(\rho=-0.3697)$ and the UN and the Republic of Korea $(\rho=-0.4051)$.

Descriptive Statistics and Correlation Matrix

Table 1

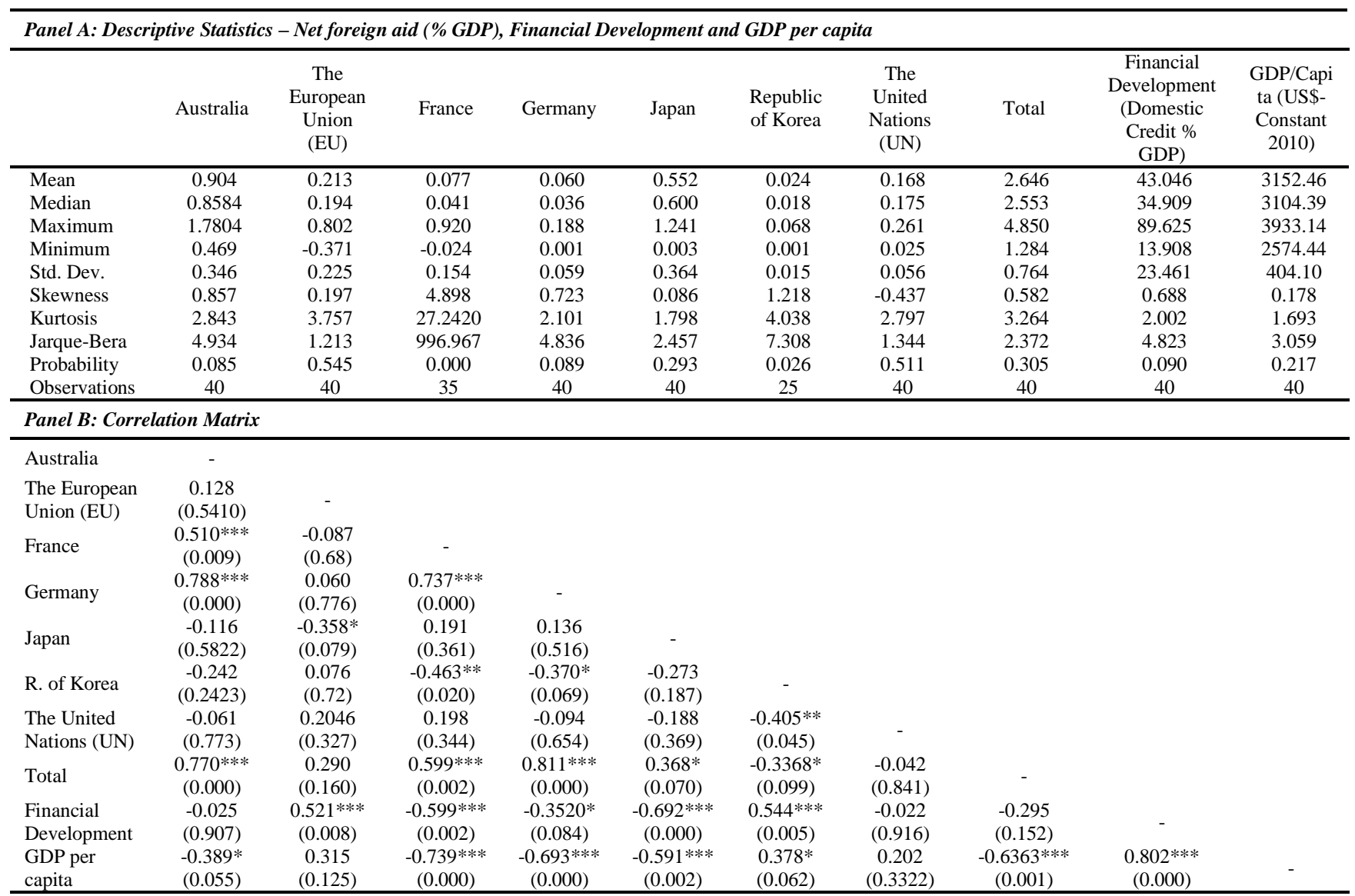

Notes: $* * *, * *$, and $*$ indicates statistical significance at $1 \%, 5 \%$ and $10 \%$ level, respectively.

Source: Authors' own estimation using Eviews 9. 
Moreover, the aid agencies (donor countries) which have a positive and statistically significant correlation with the total ODA are Australia $(\rho=0.7703)$, France $(\rho=$ $0.5985)$, Germany $(\rho=0.8108)$ and Japan $(\rho=0.3680)$; and a negative and statistically significant correlation is noted for the Republic of Korea $(\rho=-0.3368)$.

The financial sector development is significant and positively correlated with the EU $(\rho=0.5212)$ and the Republic of Korea $(\rho=0.5441)$, and negatively with France $(\rho=-0.5994)$ and Japan $(\rho=-0.6915)$. Finally, we note that GDP per capita (proxy for economic growth) is significant and positively correlated with the aid assistance from the Republic of Korea $(\rho=0.3781)$ and financial development (0.8201); and negatively correlated aid assistance from: Australia $(\rho=-0.3890)$, France $(\rho=-0.7388)$, Germany $(\rho=$ $-0.6934)$, and the total ODA $(\rho=-0.6363)$.

\section{Regression Results}

The estimated results based on equations 5.1 and 5.2 are estimated separately. We make an assessment of the cointegration (long-run association) between aid donors (ODA as dependent variable), and economic growth, financial development, procurement legislation and economic/ political crisis (as explanatory variables). As noted in Table 2, Panel 4, since the F-statistic is more than the upper critical bounds for all donor countries including the total aid at $5 \%$ level of statistical significance (Table 2, Panel 4), there is sufficient evidence of a long-run association between these variables. This implies that there is a long-run effect of at least one of the explanatory variables (depending on the level of statistical significance) on the net bi-lateral aid and the total ODA inflows to Fiji.

Subsequently, the diagnostic tests are reviewed and the short-run and long-run results are reported in Table 2. The tests include: the Lagrange multiplier (LM) test of residual serial correlation $\left(\chi^{2}\right.$ sc $)$, the Ramsey's (RESET) test using the square of the fitted values for correct functional form $\left(\chi^{2} \mathrm{ff}\right)$, the normality test based on the test of skewness and kurtosis of residuals $\left(\chi^{2} n\right)$ and the heteroscedasticity test based on the regression of squared residuals on squared fitted values $\left(\chi^{2} \mathrm{hc}\right)$. The results (Table 2, Panel 3) in general show the equations have performed well as the disturbance terms are normally distributed and serially uncorrelated with homoscedasticity of residuals. Based on the CUSUM and CUSUMQ plots, we report the parameters in the models are stable over time (bottom of Panel 3, Table 2).

\section{Short-Run Results}

In the short-run (Table 2, Panel 2), a non-linear relationship between aid and growth is noted for the donors, Australia and the EU (U-shape), and Japan (inverted Ushape), which implies that in case of aid assistance from Australia and the EU, there is a minimum threshold of growth necessary to trigger higher flows of aid. In retrospect, Fiji experienced lower growth during times of political crisis, and it is during these times, aid flows from Australia and the EU are reduced or even stopped until the country stabilizes democratically. On the other hand, we note that in the case of Japan, a lower growth rate is associated with higher inflows of aid which implies that after a certain threshold (maximum) growth rate, aid flows from Japan is expected to decline. This relationship is justified by the fact that development assistance from Japan has been fairly consistent despite the low economic growth and political crisis.

The financial development has a positive and statistically significant association with aid assistance from the EU (0.505) and the overall aid (0.430). A positive, however, not statistically significant, association is noted with aid assistance from Australia (0.559), France (0.031) and the UN (0.752). However, we note that financial development has a negative association with aid assistance from Germany (-1.767) which may be due to distance and communication barriers, financial disconnectedness, among other things.

We also note that in the short-run, the coefficient of procurement legislation is positive, however not statistically significant for the aid assistance from Australia (0.387), France (0.010), Germany (0.289), the total aid (0.278), but statistically significant for the Republic of Korea (0.604). This implies that in the short-run, aid flows from the Republic of Korea are positively influenced by the public procurement legislation. Moreover, we note that the coefficient of the public procurement legislation is negative, however, not statistically significant for the EU (-0.061) and Japan (-0.056).

In regards crisis, which includes political crisis (three coups) and the global financial crisis, we note a negative and statistically significant effect on aid inflows from France (0.087 ) and the total aid. Moreover, we also note a negative however, not statistically significant association for aid assistance from Australia (-0.047), the EU (-0.101), Germany (-0.010), Japan (-0.038) and the UN (-0.101). On the other hand, interestingly, we note that the Republic of Korea has a positive and statistically significant coefficient for crisis (0.574), which implies that in the crisis periods, development assistance from the Republic of Korea increases, possibly due to the fact that public procurement legislation has a net positive effect duly creating confidence, or simply and perhaps realistically, that aid assistance from the Republic of Korea is not sensitive to the political and economic climate of the recipient country.

Finally, the coefficient of the lag-one error correction term, which indicates the speed of adjustment to the longrun equilibrium given the previous period shocks, is negative and statistically significant within $-1<E C M_{t-1}<0$, for all cases.

\section{Long-Run Results}

In the long-run, we note that economic growth and bilateral donor aid has an inverted U-shape relationship in case of Australia, Japan, UN and the overall aid. This implies that development assistance will increase up to a certain threshold of GDP per capita. In other words, the inverted U-shape relationship signifies that development assistance are provided to support economic growth for a country in its developing stages, and Fiji is not an exception. 
Short-Run and Long-Run Impact of Procurement Legislation on Aid Inflows

\begin{tabular}{|c|c|c|c|c|c|c|c|c|}
\hline Regressor & Australia & $\begin{array}{c}\text { The European } \\
\text { Union (EU) }\end{array}$ & France & Germany & Japan & $\begin{array}{c}\text { Republic of } \\
\text { Korea }\end{array}$ & $\begin{array}{c}\text { The United } \\
\text { Nations (UN) }\end{array}$ & Total Aid \\
\hline \multicolumn{9}{|c|}{ Panel 1: Long-run - Dependent variable is $\ln O D A$} \\
\hline $\ln G D P$ & $82.673 * *$ & 0.267 & -0.605 & $-8.172 *$ & $476.303 * *$ & $8.580 * *$ & $-89.117 * *$ & $45.667 * *$ \\
\hline $\ln G D P^{2}$ & $-5.402 * *$ & - & - & - & $-29.826 * *$ & - & $5.644 * *$ & $-2.961 * *$ \\
\hline $\ln F I N$ & $0.648^{*}$ & $0.793 * * *$ & 0.058 & $2.485^{*}$ & 0.682 & $1.455^{* *}$ & $-0.557 * * *$ & $0.504 * * *$ \\
\hline$P R O C \_L E G$ & $0.505 * * *$ & $0.134 *$ & 0.008 & $1.520 *$ & -0.573 & 0.119 & -0.262 & $0.358 * * *$ \\
\hline Crisis & 0.025 & -0.098 & -0.002 & 0.754 & -0.005 & $1.112 * *$ & -0.075 & $-0.195^{* *}$ \\
\hline TREND & - & $-0.038 * * *$ & - & $-0.141 *$ & - & $-0.223 * *$ & - & $-0.017^{*}$ \\
\hline \multicolumn{9}{|c|}{ Panel 2: Short-run - Dependent variable is $\triangle \ln O D A$} \\
\hline$\Delta \ln G D P_{t}$ & $-138.661 * *$ & 0.254 & -0.243 & -3.023 & $200.977 *$ & $4.899 * *$ & $-166.786^{* * *}$ & 18.226 \\
\hline$\Delta \ln G D P_{t}^{2}$ & $8.558 * *$ & - & - & - & $-12.645^{*}$ & - & $10.546^{* * *}$ & -1.181 \\
\hline$\Delta \ln F I N_{t}$ & 0.559 & $0.505^{* *}$ & 0.031 & $-1.767 *$ & -0.196 & -0.111 & 0.752 & $0.430^{*}$ \\
\hline$\triangle P R O C_{-} L E G$ & 0.387 & -0.061 & 0.010 & 0.289 & -0.056 & $0.604 *$ & -0.337 & 0.278 \\
\hline$\Delta$ Crisis & -0.047 & -0.101 & $-0.087 *$ & -0.010 & -0.038 & $0.574 * * *$ & -0.101 & $-0.164 * *$ \\
\hline Constant & $-245.468 * * *$ & $-2.865^{* * *}$ & $3.791 * * *$ & $25.705^{* * *}$ & $-856.636^{* * *}$ & $-41.254 * * *$ & $307.356^{* * *}$ & $-149.667 * * *$ \\
\hline$E C M_{t-1}$ & $-0.771^{* * *} *$ & $-0.807 * * *$ & $-0.801 * * *$ & $-0.444 * * *$ & $-0.450 * * *$ & $-0.585^{* * *}$ & $-0.874 * * *$ & $-0.850 * * *$ \\
\hline \multicolumn{9}{|c|}{ Panel 3: Diagnostics Tests } \\
\hline $\begin{array}{l}\text { Serial Correlation } \\
\left(\chi_{s c}^{2}\right)\end{array}$ & $\begin{array}{c}\chi^{2}(1)=0.003 \\
{[0.95],} \\
F(1,38)= \\
0.003[0.96]^{\mathrm{A}}\end{array}$ & $\begin{array}{c}\chi^{2}(1)=0.539 \\
{[0.46],} \\
F(1,31)= \\
0.434[0.52]^{\mathrm{A}}\end{array}$ & $\begin{array}{c}\chi^{2}(1)= \\
0.895[0.34] \\
\mathrm{F}(1,27)= \\
0.730 \\
{[0.40]^{\mathrm{A}}}\end{array}$ & $\begin{array}{c}\chi^{2}(1)= \\
0.005[0.94] \\
\mathrm{F}(1,32)= \\
0.004 \\
{[0.95]^{\mathrm{A}}}\end{array}$ & $\begin{array}{c}\chi^{2}(1)=0.128 \\
{[0.72],} \\
\mathrm{F}(1,27)= \\
0.099[0.78]^{\mathrm{A}}\end{array}$ & $\begin{array}{c}\chi^{2}(1)=0.179 \\
{[0.67],} \\
F(1,16)= \\
0.115[0.74]^{\mathrm{A}}\end{array}$ & $\begin{array}{c}\chi^{2}(1)=0.983 \\
{[0.32],} \\
F(1,37)= \\
0.808[0.37]^{\mathrm{A}}\end{array}$ & $\begin{array}{c}\chi^{2}(1)=0.213 \\
{[0.64],} \\
F(1,36)= \\
0.171[0.68]^{\mathrm{A}}\end{array}$ \\
\hline Functional Form $\left(\chi_{f f}^{2}\right)$ & $\begin{array}{c}\chi^{2}(1)=1.155 \\
{[0.26],} \\
F(1,38)= \\
1.334[0.30]^{\mathrm{A}}\end{array}$ & $\begin{array}{c}\chi^{2}(1)=0.798 \\
{[0.43],} \\
F(1,31)= \\
0.636[0.43]^{\mathrm{A}}\end{array}$ & $\begin{array}{c}\chi^{2}(1)= \\
0.217[0.83], \\
F(1,27) \\
=0.047 \\
{[0.83]^{\mathrm{A}}}\end{array}$ & $\begin{array}{c}\chi^{2}(1)= \\
0.875 \\
{[0.39]} \\
F(1,32) \\
=0.766 \\
{[0.39]^{\mathrm{A}}}\end{array}$ & $\begin{array}{c}\chi^{2}(1)=0.819 \\
{[0.42]} \\
F(1,27) \\
=0.670 \\
{[0.42]^{\mathrm{A}}}\end{array}$ & $\begin{array}{c}\chi^{2}(1)=1.672 \\
{[0.11]} \\
F(1,16) \\
=2.797 \\
{[0.114]^{\mathrm{A}}}\end{array}$ & $\begin{array}{c}\chi^{2}(1)=2.689 \\
{[0.01],} \\
F(1,37) \\
=7.235[0.01 \\
1]^{\mathrm{C}}\end{array}$ & $\begin{aligned} & \chi^{2}(1) \\
= & 0.665 \\
& {[0.51], } \\
& \mathrm{F}(1,36) \\
= & 0.442 \\
& {[0.51]^{\mathrm{A}} }\end{aligned}$ \\
\hline Normality $\left(\chi^{2}{ }_{n}\right)$ & $\begin{array}{c}\chi^{2}(2)= \\
19.823[0.00]\end{array}$ & $\begin{array}{c}\chi^{2}(2)=0.1534 \\
{[0.93] \mathrm{A}}\end{array}$ & $\begin{array}{c}\chi^{2}(2)= \\
582.94 \\
{[0.00]}\end{array}$ & $\begin{array}{c}\chi^{2}(2)= \\
6.01[0.05]^{\mathrm{B}}\end{array}$ & $\begin{array}{c}\chi^{2}(2)= \\
0.162[0.92]^{\mathrm{A}}\end{array}$ & $\begin{array}{c}\chi^{2}(2)= \\
0.523[0.77]^{\mathrm{A}}\end{array}$ & $\begin{array}{c}\chi^{2}(2)= \\
17.709[0.00]\end{array}$ & $\begin{array}{c}\chi^{2}(2)= \\
0.341[0.84]^{\mathrm{A}}\end{array}$ \\
\hline $\begin{array}{l}\text { Heteroskedasticity } \\
\left(\chi^{2} h c\right)\end{array}$ & $\begin{array}{c}\chi^{2}(1)= \\
0.106[0.74] \\
F(1,45)= \\
0.101[0.75]^{\mathrm{A}}\end{array}$ & $\begin{array}{c}\chi^{2}(1)=2.226 \\
{[0.14],} \\
F(1,36)= \\
2.240[0.14]^{\mathrm{A}}\end{array}$ & $\begin{array}{c}\chi^{2}(1)= \\
0.002[0.97] \\
\mathrm{F}(1,31)= \\
0.002 \\
{[0.97]^{\mathrm{A}}}\end{array}$ & $\begin{array}{c}\chi^{2}(1)= \\
0.035[0.85], \\
\mathrm{F}(1,38)= \\
0.033 \\
{[0.86]^{\mathrm{A}}}\end{array}$ & $\begin{array}{c}\chi^{2}(1)= \\
0.512[0.47] \\
\mathrm{F}(1,32)= \\
0.489[0.49]^{\mathrm{A}}\end{array}$ & $\begin{array}{c}\chi^{2}(1)= \\
0.417[0.52], \\
\mathrm{F}(1,22)= \\
0.389[0.54]^{\mathrm{A}}\end{array}$ & $\begin{array}{c}\chi^{2}(1)= \\
1.101[0.29] \\
F(1,43)= \\
1.078[0.31]^{\mathrm{A}}\end{array}$ & $\begin{array}{c}\chi^{2}(1)= \\
0.0567 \\
{[0.81],} \\
\mathrm{F}(1,42)= \\
0.054[0.82]^{\mathrm{A}}\end{array}$ \\
\hline CUSUM & Stable & Stable & Stable & Stable & Stable & Stable & Stable & Stable \\
\hline CUSUMQ & Stable & Stable & Stable & Stable & Stable & Stable & Stable & Stable \\
\hline$R$-square & 0.601 & 0.589 & 0.264 & 0.816 & 0.630 & 0.748 & 0.475 & 0.685 \\
\hline Adj. R-Square & 0.519 & 0.442 & 0.132 & 0.777 & 0.550 & 0.644 & 0.378 & 0.625 \\
\hline DW-Stat & 1.930 & 2.566 & 2.110 & 1.988 & 1.852 & 2.135 & 2.197 & 2.061 \\
\hline \multicolumn{9}{|c|}{ Panel 4: Cointegration - ARDL Bounds } \\
\hline Trend Specification & $\begin{array}{l}\text { Unrestricted } \\
\text { Constant }\end{array}$ & $\begin{array}{c}\text { Restricted } \\
\text { Linear Trend }\end{array}$ & $\begin{array}{c}\text { Unrestricted } \\
\text { Constant }\end{array}$ & $\begin{array}{c}\text { Restricted } \\
\text { Linear Trend }\end{array}$ & $\begin{array}{c}\text { Unrestricted } \\
\text { Constant }\end{array}$ & $\begin{array}{c}\text { Restricted } \\
\text { Linear Trend }\end{array}$ & $\begin{array}{c}\text { Unrestricted } \\
\text { Constant }\end{array}$ & $\begin{array}{c}\text { Restricted } \\
\text { Linear Trend }\end{array}$ \\
\hline \# Regressors (k) & 3 & 3 & 2 & 2 & 3 & 2 & 3 & 3 \\
\hline \# models evaluated & 8 & 4 & 4 & 4 & 8 & 4 & 8 & 8 \\
\hline$F$-statistics & $9.23 * * *$ & $7.71 * * *$ & $7.24 * * *$ & $4.75^{* *}$ & $4.14^{* *}$ & $11.73 * * *$ & $14.95 * * *$ & 6.277066 \\
\hline $1 \%: I(0)-I(1)$ & $4.29-5.61$ & $4.29-5.61$ & $5.15-6.36$ & $4.99-5.85$ & $4.29-5.61$ & $4.99-5.85$ & $4.29-5.61$ & $4.30-5.23$ \\
\hline $5 \%: I(0)-I(1)$ & $3.23-4.35$ & $3.23-4.35$ & $3.79-4.85$ & $3.88-4.61$ & $3.23-4.35$ & $3.88-4.61$ & $3.23-4.35$ & $3.38-4.23$ \\
\hline $10 \%: I(0)-I(1)$ & $2.72-3.77$ & $2.72-3.77$ & $3.17-4.14$ & $3.38-4.02$ & $2.72-3.77$ & $3.38-4.02$ & $2.72-3.77$ & $2.97-3.74$ \\
\hline$A R D L$ & $1,1,1,0$ & $1,0,0$ & $1,0,0,0$ & $1,0,1$ & $1,0,0,0$ & $1,0,1$ & $1,0,0,1$ & $1,0,0,0$ \\
\hline$N$-after adjustment & $\begin{array}{c}48 \\
(1967-2014)\end{array}$ & $\begin{array}{c}39 \\
(1976-2014)\end{array}$ & $\begin{array}{c}34 \\
(1981-2014)\end{array}$ & $\begin{array}{c}41 \\
(1974-2014)\end{array}$ & $\begin{array}{c}35 \\
(1980-2014)\end{array}$ & $\begin{array}{c}25 \\
(1990-2014)\end{array}$ & $\begin{array}{c}46 \\
(1969-2014)\end{array}$ & $\begin{array}{c}45 \\
(1970-2014)\end{array}$ \\
\hline
\end{tabular}

Notes: ***,**, and * refers to 1,5 , and $10 \%$ level of significance, respectively; A, B - indicates rejection of respective biasness at $1 \%$ and $5 \%$ level of statistical significance.

Source: Authors' own estimation using Eviews 9.

As noted from the overall aid (\%GDP), while the relationship is non-linear (and inverted U-shaped), aid assistance from some bilateral donors exhibit a linear relationship. A positive relationship is noted for the EU (0.267) and the Republic of Korea (8.580), where only the latter is statistically significant. A negative association is noted for France (-0.605) and Germany (-8.172), where only the latter is statistically significant. This highlights the heterogeneity among development assistance providers and alludes to the various reasons and motivations of providing aid to a developing country like Fiji. ${ }^{1}$

In regards financial development, although we note a negative association with aid assistance from the UN (0.557), aid assistance from other donor countries including the total aid show a positive association. In other words, a positive and statistically significant relationship is noted for Australia (0.648), the EU (0.793), Germany (2.485) and the Republic of Korea (1.455), and the total aid assistance

\footnotetext{
${ }^{1}$ However, teasing out the specific objectives for aid assistance to Fiji is beyond the scope of this paper.
} 
(0.504), which implies that financial sector development is supportive of aid inflows to Fiji.

Interestingly, we note that procurement legislation has a positive and statistically significant effect on aid from Australia (0.505), the EU (0.134), Germany (1.520), and the total aid (0.358) to Fiji. This implies continued adoption of the new public procurement legislation has a positive effect on the aid assistance from these donor countries and the total aid inflows.

While the effect of crisis for most of the bilateral donors are negative (the EU $=-0.098$, France $=-0.002$, Japan $=$ 0.005 , and the UN $=-0.075)$, they are not statistically significant. Moreover, the effect of crisis on aid inflow is positive for aid assistance from Australia (0.025) and Germany (0.754), however they are not statistically significant within the conventional 1-10 percent levels. Notably, the effect of crisis has a positive and statistically significant effect on the aid assistance from the Republic of Korea (1.112), which is similar to the short-run result. The overall effect of crisis on the net aid inflows to Fiji is in principal, negative (-0.195) and statistically significant at $5 \%$ level. This implies that political and financial crisis have clear adverse effect on the overall inflow of aid to Fiji. Finally, we note a negative effect of trend in the case of the EU (-0.038), Germany (-0.141), the Republic of Korea ($0.223)$ and the total aid assistance $(-0.017)$, which indicates that in the long-run, there is a gradual decline in aid inflows (as a percent of recipient country's GDP) from the donor countries.

\section{Conclusion}

In this paper, we set out to examine the impact of public procurement legislation on the flow of aid from bilateral donor countries and the total aid flows to Fiji. In our estimation, we also examine the plausibility of non-linear relationship between aid flows and the per capita income, the impact of financial sector development, and political and financial crisis on the aid inflows. At the outset, we examine the presence of a long-run association, following which the short-run and long-run results are ascertained.
At the individual donor country level, the results are mixed, both in the short-run and the long-run. This not only highlights the heterogeneity among donor countries but also shows the differences in the objectives and motivation of aid provision to a developing country like Fiji. Moreover, we note that in the long-run, aid assistance and economic growth has an inverted U-shaped relationship which implies the presence of a threshold and hence as the economy of Fiji progresses (in terms of increase in the real GDP per capita), the country will experience a decline in aid inflows (as a percent of GDP), in general. This is also supported by the negative coefficient noted by the overall trend variable. The results also coincide with the notion that with the increase in economic growth, the country will be less dependent on aid inflows.

Also, we note a clear positive effect of financial development and public procurement legislation on the aid flows. In this regard, for aid flows to remain consistent (relative to GDP), it is important that governments ensure that financial sectors are developed and sound public procurement policies are adopted to create sufficient confidence among donors. While earlier studies have shown mixed and somewhat weak positive effect of financial development on the economic growth of Fiji (Gounder, 2012; Makin, 2016), our results show a clear positive effect of financial development on aid inflows. The result indicates that bilateral donor agencies consider a relatively welldeveloped financial sector as an important consideration when determining the supply of aid. Moreover, it is also clear that the flow of aid is likely to increase in the presence of effective and well-functioning procurement policies. Thus, our results highlight that an effective and efficient financial sector and the adoption of sound public procurement policies can signal efficient mechanism to channel funds and greater transparency in the use of aid flows, respectively. However, we note that crisis such as political uncertainty and the global recession hampers aid inflows to Fiji, and therefore, democracy and political stability should be maintained, while exogenous shocks such as the global financial crisis needs to be managed through a collective solution from the donor and recipient countries.

\section{References}

Ahmadu, M. L. (2005). Evaluating public procurement regimes in the South Pacific: Perspectives on Fiji, Samoa and Vanuatu. Journal of South Pacific Law, 9(1), 1-23.

Arrowsmith, S. (1995). Public procurement as an instrument of policy and the impact of market liberalization. Law Quarterly Review, 111, 235.

Banerjee, S. G., \& Rondinelli, D. A. (2003). Does foreign aid promote privatization? Empirical evidence from developing countries. World Development, 31(9), 1527-1548. https://doi.org/10.1016/S0305-750X(03)00107-4

Bolton, P. (2006). Government procurement as a policy tool in South Africa. Journal of Public Procurement, 6(3), 193.

Bornschier, V., Chase-Dunn, C., \& Rubinson, R. (1978). Cross-national evidence of the effects of foreign investment and aid on economic growth and inequality: A survey of findings and a reanalysis. American journal of Sociology, 84(3), 651-683. https://doi.org/10.1086/226831

Burnside, C., \& Dollar, D. (2000). Aid, policies, and growth. American Economic Review, 90(4), 847-868. https://doi.org/10.1257/aer.90.4.847

Chauvet, L., \& Guillaumont, P. (2009). Aid, volatility, and growth again: When aid volatility matters and when it does not. Review of Development Economics, 13(3), 452-463. https://doi.org/10.1111/j.1467-9361.2009.00501.x

Chong, A., \& Gradstein, M. (2008). What determines foreign aid? The donors' perspective. Journal of Development Economics, 87(1), 1-13. https://doi.org/10.1016/j.jdeveco.2007.08.001 
Ronald Ravinesh Kumar, Arvind Patel, Madhukar Singh. Effect of Procurement Policy on aid Inflows in the ...

Clemente, J., Marcuello, C., \& Montanes, A. (2012). Government social spending and GDP: Has there been a change in social policy?. Applied Economics, 44(22), 2895-2905. https://doi.org/10.1080/00036846.2011.568401

Dalgaard, C. J. (2008). Donor policy rules and aid effectiveness. Journal of Economic Dynamics \& Control, 32(6), 18951920. https://doi.org/10.1016/j.jedc.2007.07.002

Dalgaard, C. J., \& Hansen, H. (2001). On aid, growth and good policies. Journal of Development Studies, 37(6), $17-41$. https://doi.org/10.1080/713601081

Dalgaard, C. J., Hansen, H., \& Tarp, F. (2004). On the empirics of foreign aid and growth. The Economic Journal, 114(496), 191-216. https://doi.org/10.1111/j.1468-0297.2004.00219.x

Engle, R. F., \& Granger, C. W. J. (1987). Co-integration and error correction: Representation, estimation, and testing. Econometrica, 55(2), 251-276. https://doi.org/10.2307/1913236

Gounder, N. (2012). Financial development and economic growth in Fiji: New empirical evidence. Fijian Studies, 9(2), 922. http://fijianstudies.net/wp-content/uploads/FS/9(2)/Neelesh.pdf.

Hansen, H., \& Tarp, F. (2001). Aid and growth regressions. Journal of Development Economics, 64(2), 547-570. https://doi.org/10.1016/S0304-3878(00)00150-4

Harrigan, J., \& Wang, C. (2011). A new approach to the allocation of aid among developing countries: Is the USA different from the rest?. World Development, 39(8), 1281-1293. https://doi.org/10.1016/j.worlddev.2010.12.011

Heckelman, J. C., \& Knack, S. (2009). Aid, economic freedom, and growth. Contemporary Economic Policy, 27(1), 46-53. https://doi.org/10.1111/j.1465-7287.2008.00123.x

Hommen, L., \& Rolfstam, M. (2009). Public procurement and innovation: Towards a taxonomy. Journal of Public Procurement, 9(1), 17-56.

Jayaraman, T. K., Chen, H., \& Bhatt, M. (2014). Research note: Contribution of foreign direct investment to the tourism sector in Fiji: an empirical study. Tourism Economics, 20(6), 1357-1362. https://doi.org/10.5367/te.2013.0358

Johansen, S., \& Juselius, K. (1990). Maximum likelihood estimation and inference on cointegration with applications to the demand for money. Oxford Bulletin of Economics and Statistics, 52(2), 169-210. https://doi.org/10.1111/j.14680084.1990.mp52002003.x

Jones, S. D. (2013). Procurement reform in the Philippines: the impact of elite capture and informal bureaucracy. International Journal of Public Sector Management, 26(5), 375-400. https://doi.org/10.1108/IJPSM-05-2013-0068

Knight, L., Caldwell, N., Harland, C., \& Telgren, J. (2003). Government reform and public procurement: Academic report of the first workshop. Budapest, Hungary: International Research Study of Public Procurement. April 10-12 2003.

Knight, L., Harland, C., Telgren, J., Thai, K. V., Callender, G., \& McKen, K. (Eds.). (2012). Public procurement: International cases and commentary. Routledge.

Kumar, R. R. \& Kumar, R. (2012). Exploring the nexus between information and communications technology, tourism and growth in Fiji. Tourism Economics, 18(2), 359-371. https://doi.org/10.5367/te.2012.0117

Kumar, R. R., \& Singh, M. (2014). Role of health expenditure and ICT in a small island economy: a study of Fiji. Quality \& Quantity, 48(4), 2295-2311. https://doi.org/10.1007/s11135-013-9892-7

Kumar, R. R., \& Stauvermann, P. J. (2014). Exploring the effects of remittances on Lithuanian economic growth. Inzinerine Ekonomika-Engineering Economics, (3), 250-260. https://doi.org/10.5755/j01.ee.25.3.6421

Kumar, R. R., \& Stauvermann, P. J. (2016). The linear and non-linear relationship between of tourism demand and output per worker: A study of Sri Lanka. Tourism Management Perspectives, 19, 109-120. https://doi.org/10.10 16/j.tmp.2016.05.005

Kumar, R. R., Kumar, R. D., \& Patel, A. (2015). Accounting for telecommunications contribution to economic growth: A study of Small Pacific Island States. Telecommunications Policy, 39(3), 284-295. https://doi.org/10.1016/ j.telpol.2014.08.005

Leao, P. (2013). The effect of government spending on the debt-to-GDP ratio: Some Keynesian arithmetic. Metroeconomica, 64(3), 448-465. https://doi.org/10.1111/meca.12013

Levy, V. (1988). Aid and growth in Sub-Saharan Africa: The recent experience. European Economic Review, 32(9), 17771795. https://doi.org/10.1016/0014-2921(88)90085-2

Llavador, H. G., \& Roemer, J. E. (2001). An equal-opportunity approach to the allocation of international aid. Journal of Development Economics, 64(1), 147-171. https://doi.org/10.1016/S0304-3878(00)00128-0

Makun, K. K. (2016). Direct foreign investments and its determinants: A case study. Economia Internazionale, 69(2), 151174. http://www.iei1946.it/upload/rivista_articoli/allegati/105_makunric100517.pdf.

McKinnon, R. I. (1964). Foreign exchange constraints in economic development and efficient aid allocation. The Economic Journal, 74(294), 388-409. https://doi.org/10.2307/2228486 
Neanidis, K. C., \& Varvarigos, D. (2009). The allocation of volatile aid and economic growth: Theory and evidence. European Journal of Political Economy, 25(4), 447-462. https://doi.org/10.1016/j.ejpoleco.2009.05.001

Odhiambo, N. M. (2009). Energy consumption and economic growth nexus in Tanzania: An ARDL bounds testing approach. Energy Policy, 37(2), 617-622. https://doi.org/10.1016/j.enpol.2008.09.077

Organisation for Economic Co-operation and Development. (2010, February). OECD/DAC methodology for assessing procurement system. Retrieved June 1, 2016, from http://www.oecd.org/development/effectiveness/45181522.pdf.

Patrick, H. T. (1966). Financial development and economic growth in underdeveloped countries. Economic Development and Cultural Change, 14(2), 174-189. https://doi.org/10.1086/450153

Pesaran, M. H., Shin, Y., \& Smith, R. (2001). Bounds testing approaches to the analysis of level relationships. Journal of Applied Econometrics, 16(3), 289-326. https://doi.org/10.1002/jae.616

Rajan, R., \& Subramanian, A. (2007). Does aid affect governance?. American Economic Review, 97(2), $322-327$. https://doi.org/10.1257/aer.97.2.322

Rao, B. B. (2010). Estimates of the steady state growth rates for selected Asian countries with an extended Solow Model. Economic Modelling, 27(1), 46-53. https://doi.org/10.1016/j.econmod.2009.07.020

Schooner, S., \& Whiteman, N. (2000). Purchase Card and micro purchases. Public Procurement Law Review, 9(4), 148170.

Shahzad, S. J. H., Kumar, R. R., Zakaria, M., \& Hurr, M. (2017). Carbon emission, energy consumption, trade openness and financial development in Pakistan: A revisit. Renewable and Sustainable Energy Reviews, 70, $185-192$. https://doi.org/10.1016/j.rser.2016.11.042

Shleifer, A. (2009). Peter Bauer and the failure of foreign aid. Cato Journal, 29(3), 379-390.

Snider, K. F., \& Rendon, R. (2008). Public procurement policy: Implications for theory and practice. Journal of Public Procurement, 8(3), 310-333.

Sobhee, S. K., \& Nath, S. (2010). Is donors' concern about the fungibility of foreign aid justified?: A panel data analysis. Journal of Developing Areas, 43(2), 299-311. https://doi.org/10.1353/jda.0.0071

Tamazian, A., \& Rao, B. B. (2010). Do economic, financial and institutional developments matter for environmental degradation? Evidence from transitional economies. Energy Economics, 32(1), 137-145. https://doi.org/10.1016/ j.eneco.2009.04.004

Trumbull, W. N., \& Wall, H. J. (1994). Estimating aid-allocation criteria with panel data. Economic Journal, 104(425), 876-882. https://doi.org/10.2307/2234981

The article has been reviewed.

Received in December, 2016; accepted in December, 2017. 